\title{
Elevated levels of ingested plastic in a high Arctic seabird, the northern fulmar (Fulmarus glacialis)
}

\author{
Alice M. Trevail • Geir W. Gabrielsen • \\ Susanne Kühn · Jan A. Van Franeker
}

Received: 18 November 2014/Revised: 1 February 2015/ Accepted: 5 February 2015/Published online: 13 February 2015

(C) The Author(s) 2015. This article is published with open access at Springerlink.com

\begin{abstract}
Plastic pollution is of worldwide concern; however, increases in international commercial activity in the Arctic are occurring without the knowledge of the existing threat posed to the local marine environment by plastic litter. Here, we quantify plastic ingestion by northern fulmars, Fulmarus glacialis, from Svalbard, at the gateway to future shipping routes in the high Arctic. Plastic ingestion by Svalbard fulmars does not follow the established decreasing trend away from human marine impact. Of 40 sampled individuals, 35 fulmars $(87.5 \%)$ had plastic in their stomachs, averaging at $0.08 \mathrm{~g}$ or 15.3 pieces per individual. Plastic ingestion levels on Svalbard exceed the ecological quality objective defined by OSPAR for European seas. This highlights an urgent need for mitigation of plastic pollution in the Arctic as well as international regulation of future commercial activity.
\end{abstract}

Keywords Plastic pollution - Arctic · Human impact . Northern fulmar $\cdot$ Climate change

\footnotetext{
A. M. Trevail $(\bowtie) \cdot$ G. W. Gabrielsen

FRAM, High North Research Centre for Climate and the Environment, Norwegian Polar Institute, 9296 Tromsö, Norway e-mail: alice.trevail@npolar.no

S. Kühn · J. A. Van Franeker IMARES, PO Box 167, 1790AD Den Burg, Texel, The Netherlands

S. Kühn

University Centre of the Westfjords, Ísafjörður, Iceland
}

\section{Introduction}

The threat of pollution in the Arctic is rising as commercial activity (such as shipping) increases, enabled by rapid sea ice decline (Kerr 2012) and driven by global politics and economic demand (Brigham 2011). The Arctic is currently an area of relatively low direct human impact (Halpern et al. 2008); however, increased shipping may put areas of high biodiversity at risk (Humphries and Huettmann 2014). Indeed, shipping density has previously been linked to the prevalence of plastic ingestion by marine life as well as concentration of coastal human populations (Van Franeker et al. 2011; Kühn and Van Franeker 2012). The global plastic industry is continuously expanding (Plastics Europe 2013), the use of disposable plastic products persists (WRAP 2014), and it is likely that the already significant amounts of plastic litter entering the marine environment will increase (Law and Thompson 2014). Latest estimates suggest that globally there is a minimum of 5.25 trillion pieces of plastic weighing 268,940 t floating on the ocean surface alone (Eriksen et al. 2014). The deleterious impacts of plastic litter are numerous, including transport of pollutants (Zarfl and Matthies 2010) and invasive species (Barnes 2002), entanglement with and ingestion by marine fauna (Laist 1997), as well as economic costs (Mouat et al. 2010; Leggett et al. 2014). Considering this, there is an urgent need for a quantitative assessment of plastic pollution levels in the Arctic. Such an assessment can provide information for the development of international regulation to protect the marine environment for the future (Brigham 2011), as well as a tool for monitoring potential impacts of future commercial activity.

Plastic ingestion has been documented in over 100 species of seabird (Laist 1997). This has led to the identification of species with characteristics that make them 
suitable as biological monitors of trends in plastic pollution (Van Franeker 1985; Van Franeker et al. 2011). Northern fulmars (Fulmarus glacialis) have been extensively used as an indicator species for plastic pollution levels in the Northern Hemisphere since they were first used for monitoring around the North Sea in the 1980s (Van Franeker et al. 2011). At present, data exist for much of the North-East Atlantic (Van Franeker et al. 2011; Kühn and Van Franeker 2012), the Canadian Arctic (Provencher et al. 2009) and the eastern North Pacific (Avery-Gomm et al. 2012; Donnelly-Greenan et al. 2014). Northern fulmars are entirely oceanic feeders (Weimerskirch et al. 2001; Garthe et al. 2004), and their omnivorous foraging behaviour (Hamer et al. 1997) renders them particularly vulnerable to plastic ingestion (Van Franeker et al. 2011). Hard prey items, including plastic, remain in a fulmar's muscular stomach until they are broken down to a size that can pass through the gut, within approximately 1 month (Van Franeker et al. 2011). Therefore, stomach plastic contents represent a recent period prior to death, and thus plastic pollution in their foraging area (Van Franeker et al. 2011).

Within Europe, northern fulmars are defined by the Oslo-Paris Convention (OSPAR) for the North-East Atlantic as an indicator species of plastic pollution (OSPAR 2008). OSPAR recommendations state that for acceptable ecological quality (EcoQO), $<10 \%$ of the monitored population of northern fulmars should have more than $0.1 \mathrm{~g}$ of plastic in the stomach (OSPAR 2008).

Levels of plastic pollution typically decrease away from areas of high human impact and commercial activity, thereby often decreasing towards the poles (Barnes 2002, 2005; Kühn and Van Franeker 2012). This decrease can be attributed to the main sources of plastic to the ocean, including accidental losses during transport, irresponsible human behaviour, improper waste management and loss during natural disasters. However, there is no complete or recent information regarding plastic ingestion by northern fulmars at the highest breeding latitudes in Europe. Svalbard, in the European Arctic, is an area of high seabird biodiversity (Humphries and Huettmann 2014) where there will likely be a substantial increase in shipping traffic in the years to come (Smith and Stephenson 2013) and therefore potential increases in plastic pollution. Although the Arctic has long lost its wilderness status (France 1992), measurements of the extent of anthropogenic litter in the European Arctic only exist for the seafloor (Bergmann and Klages 2012).

To assess plastic pollution levels in the European Arctic, this study quantified the amount of plastic ingested by northern fulmars from Spitsbergen, the largest island of the Svalbard archipelago. In the 1980s, plastic ingestion by fulmars from Spitsbergen and Bear Island (mid-way between Spitsbergen and mainland Norway) was observed during diet studies (Gjertz et al. 1985; Lydersen et al. 1985; Van Franeker 1985; Lydersen and Gjertz 1989). However, the mass of plastic was not recorded and data from Spitsbergen are incomplete; therefore, a temporal comparison with 1980s data is not possible. This study will be the first dedicated study of plastic ingestion by arctic fulmars in this area, and thus represents a valuable northwards expansion of ongoing Atlantic/North Sea monitoring efforts. This paper presents the results from Svalbard, alongside analysis of spatial trends.

\section{Materials and methods}

This project is registered in the 'Research in Svalbard' (RiS) database, within the Svalbard Science Forum (Project ID: 6355). Permission to sample fulmars was granted by Sysselmannen, the governing body on Svalbard. A total of 40 fulmars were shot outside of the breeding season for a broad range of research purposes, in collaboration with other research groups. This method was selected because of the absence of longline fisheries in the Svalbard area, from which it would otherwise be possible to collect bycatch individuals (e.g. Kühn and Van Franeker 2012). In addition, collecting beached individuals is infeasible because of rapid scavenging (e.g. by polar foxes, arctic skuas, great skuas, glaucous gulls) and inaccessibility of beaches. Furthermore, stomach flushing alone would likely not give a full representation of stomach contents, as many of the hard items would remain in the gizzard: the muscular section of the stomach. A sample size of 40 has been recommended to quantify plastic ingestion with statistical confidence in fulmars (Van Franeker and Meijboom 2002).

\section{Ethics statement}

Sampling was carried out in accordance with high EU standards and best professional practices, and all efforts were made to minimise suffering. Collaboration with other studies (e.g. samples for diet studies, stable isotope analysis studies, tissue contaminant studies for POPs and heavy metals by Norwegian scientists, and tissue radionuclide studies by Japanese scientists investigating the fallout from Fukushima 2011) ensured maximum sampling from killed individuals.

Fulmars were sampled in Isfjord, Svalbard $\left(78.3^{\circ} \mathrm{N}\right.$, $16.1^{\circ} \mathrm{E}$ ), from 21 to 23 September 2013. Dissections were undertaken at the University Centre in Svalbard (UNIS), Longyearbyen, following the protocol used by the North Sea monitoring programme (Van Franeker 2004) to determine age and sex as well as morphological characteristics. Stomachs were collected whole, and both the proventriculus and gizzard were rinsed over a 1-mm sieve. 
Stomach plastic contents were characterised and quantified with IMARES (Texel, Netherlands) according to the North Sea monitoring protocol (Van Franeker et al. 2011): plastic pieces were counted and weighed by category once dry on a electronic Sartorius scale accurate to 0.0001 g. Plastics were sorted visually into industrial plastics: raw plastic pellets produced by plastic manufacturers, and user plastics: all forms of plastic used by consumers, such as fragments of hard plastics, sheets, threads or foams.

Data were compared to other regions where plastic loading in northern fulmar stomachs has been monitored. Data were provided from Jan Van Franeker for the most recent 5-year period (2007-2011) in the English Channel, the North Sea (comprising of East England, the Scottish Islands, Belgium, Germany, the Netherlands, Denmark and the North Sea coasts of Sweden and South Norway) and the Faroe Islands, published within the 'Save the North Sea' monitoring work (Van Franeker and SNS Fulmar Study Group 2013) as well as for Iceland for 2011 (Kühn and Van Franeker 2012). Summary data for Arctic Canada were also used for comparison (Mallory et al. 2006; Mallory 2008; Provencher et al. 2009).

All data analyses were carried out using $\mathrm{R}$ version 3.1.0. Regional averages are presented as the arithmetic mean (unless otherwise stated) using all individuals, including those with no ingested plastic. Data were not normally distributed before or after relevant transformation (Shapiro-Wilk $p<0.05)$; therefore, nonparametric tests (Mann-Whitney $U$ test or Kruskal-Wallis) were used to compare regional differences in plastic ingestion. In addition, the geometric mean and OSPAR EcoQO performance were calculated to minimise the effect of outliers, as per previous monitoring work (Kühn and Van Franeker 2012).

\section{Results}

As determined from dissections (Van Franeker 2004), 5 out of the 40 fulmars were adults, 7 were second-year birds (i.e. chicks of 2012), and the remainder were sub-adults (ca. 3-5 or more years old, having never bred before). None of the fulmars sampled in September had bred during the summer of 2013, determined by the lack of remnants of a brood patch. Sexes were equally represented with 21 females and 19 males. All birds were of the arctic 'coloured' type (colour phases L, D and DD as in Van Franeker (2004)). No fulmars were of the light plumage colour that dominates in colonies south of the Arctic.

Plastic ingestion by fulmars on Svalbard

On Svalbard, 35 fulmars $(87.5 \%)$ of the 40 sampled individuals contained plastic (i.e. the incidence rate), equating to an average of 15.3 pieces $( \pm$ s.e. $=5.5, n=40)$ of plastic per individual or an average total mass of $0.08 \mathrm{~g}( \pm 0.02 \mathrm{~g})$ per individual. Full details of stomach plastic are given in Tables 1 and 2. The maximum stomach plastic contents by both number and weight were recorded in the same individual: 200 pieces, weighing $0.4990 \mathrm{~g}$. Industrial plastic pellets made up on average $10.8 \%( \pm 4.5 \%)$ of the mass of all stomach plastic content in individual fulmars; the remainder of which was user plastic. An example of stomach plastic content is given in Fig. 1.

In this study we found that on Svalbard, $22.5 \%$ of northern fulmars have $\geq 0.1 \mathrm{~g}$ of plastic in their stomach, which exceeds the level defined by OSPAR as the Ecological Quality Objective for the North Sea (EcoQO; $10 \%)$.

The amount of plastic in stomachs of fulmars in this study did not differ between male and female birds in terms of both mass ingested and number of pieces (MannWhitney $U$ test, $p>0.05)$. Similarly, we found no statistical difference in stomach plastic content between the different age groups sampled in this study (Mann-Whitney $U$ test, $p>0.05$ ) or by the different colour morphs of fulmars (Mann-Whitney $U$ test, $p>0.05$ ).

\section{Latitudinal comparison}

Plastic content of fulmar stomachs from Svalbard was compared to monitoring data from multiple regions in the North-East Atlantic (Fig. 2). Overall, incidence of stomach plastic differs significantly between study regions in the North Atlantic (mass and number of pieces; KruskalWallis, $p<0.05)$.

From the English Channel north to Arctic Canada, there is a decrease in stomach plastic incidence and mass with latitude (Fig. 3). However, plastic content (incidence and mass) is greater on Svalbard than at lower latitudes in Arctic Canada. In addition, there is no difference in the amount of plastic (mass and number of pieces) in stomachs of northern fulmars from Svalbard and Iceland, (MannWhitney $U$ test, $p>0.05)$. On Svalbard, the incidence of stomach plastic was higher than on Iceland (Fig. 3a), although mass was similar in the two locations (Fig. 3b-d). The geometric mean masses of stomach plastic on Iceland and Svalbard are 0.020 and $0.024 \mathrm{~g}$, respectively.

\section{Discussion}

This study has achieved a baseline value of plastic ingestion by fulmars that will facilitate the future detection of changes in marine plastic pollution and potential impacts of increased commercial activity. 


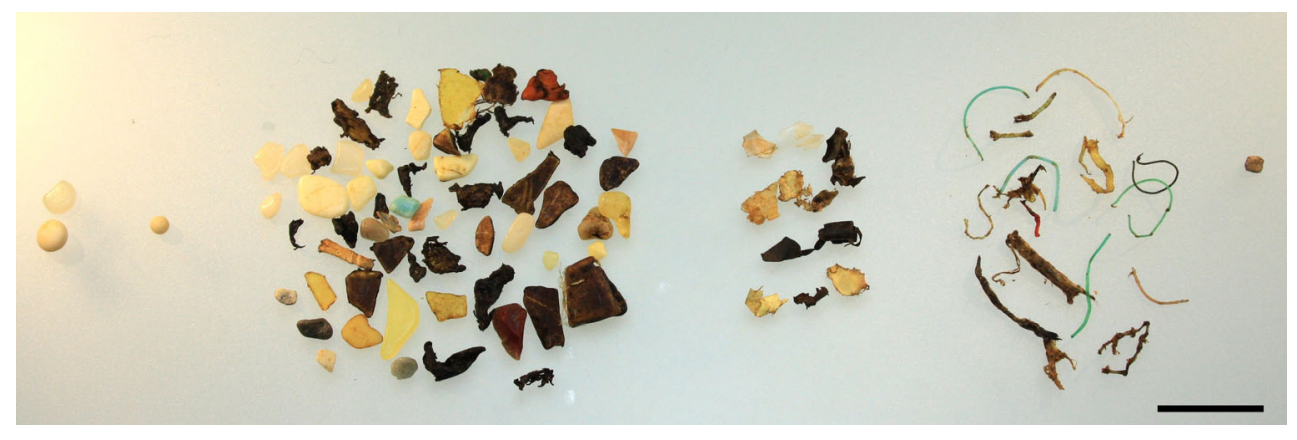

Fig. 1 Stomach plastic contents of an individual northern fulmar from Svalbard, 2013. L-R: Industrial pellets; probably industrial; fragments; sheets; threads; foam. Scale bar indicates $1 \mathrm{~cm}$

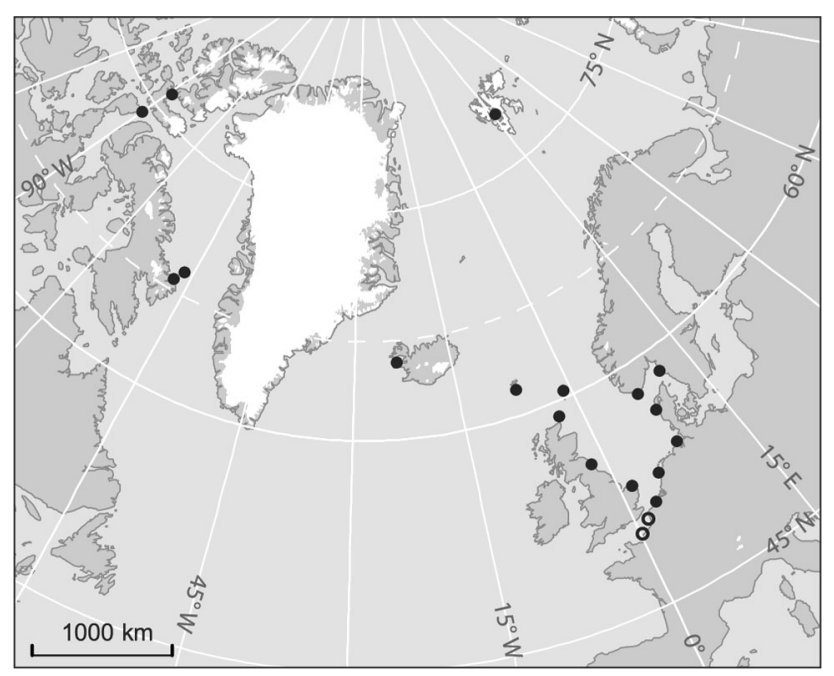

Fig. 2 Map showing all study locations used for regional comparison of plastic ingestion by northern fulmars: Svalbard (Sva.), Arctic Canada (Can.), Iceland (Ice.), Faroe Islands (Far.), the North Sea (N. Sea) and the English Channel (E. Ch.; hollow circles). White shading indicates ice cover. Dashed line gives limit of the Arctic Circle around $66^{\circ} 33^{\prime} 44^{\prime \prime} \mathrm{N}$

Unfortunately, data for the 1980s (Gjertz et al. 1985; Lydersen et al. 1985; Van Franeker 1985; Lydersen and Gjertz 1989) do not allow a proper analysis for possible changes over time in stomach plastic content. The data in these early publications give only the number of items and appear contradictory between information for Spitsbergen (29\% individuals with plastic $(n=62)$, and an average of 0.75 pieces $(n=20)$ in Gjertz et al. (1985), Lydersen et al. (1985) and Lydersen and Gjertz (1989)) and nearby Bear Island (82\% individuals with plastic and an average of 4.5 pieces $(n=22)$ in Van Franeker (1985)). Furthermore, from North Sea fulmar data, it appears that sizes of plastic particles have changed over time: particles have become smaller (Van Franeker and Meijboom 2002), with currently different number to mass ratios than in the 1980s, which complicates comparisons.
As expected from North Sea data in (Van Franeker et al. 2011), the data in Table 1 do suggest differences between young and adult birds, but the small sample size for adults prevents robust statistical evaluation in this case. However, adults and non-adults are similar in EcoQO performance and allow combined further discussion in this baseline. Later studies need to provide more insight into potential age differences and their implications for interpretation of plastic monitoring data.

Plastic in stomachs of northern fulmars on Svalbard does not follow the established trend of a decrease with latitude or distance from human marine impact (using measure of impact from Halpern et al. (2008)). Instead, stomach plastic content of fulmars from Svalbard is higher than expected. This study reports the highest levels of plastic ingestion reported in an Arctic colony of northern fulmars. Incidence of stomach plastic and mass of stomach plastic are considerably higher than those recorded at lower latitudes in Arctic Canada (Mallory et al. 2006; Mallory 2008; Provencher et al. 2009). In addition, levels of stomach plastic on Svalbard are comparable to those on Iceland, approximately $2,000 \mathrm{~km}$ further south, contrary to the expected latitudinal decrease (Kühn and Van Franeker 2012).

Although foraging distance of fulmars can be large (Edwards et al. 2013), it may be that the individuals sampled were exhibiting central-place foraging, as found in immature birds following the breeding period in other species (Votier et al. 2010; Riotte-Lambert and Weimerskirch 2013). Indeed, sampled fulmars from Svalbard were all of the darker colour phase, of which very few (10\%) are found in the northern North Sea regions in the month prior to sampling (Van Franeker, unpublished). Those that are found in the northern North Sea are predominately younger still than the sample of fulmars in this study. It is therefore probable that the plastic in their stomachs was ingested locally, rather than in more polluted regions further south. 

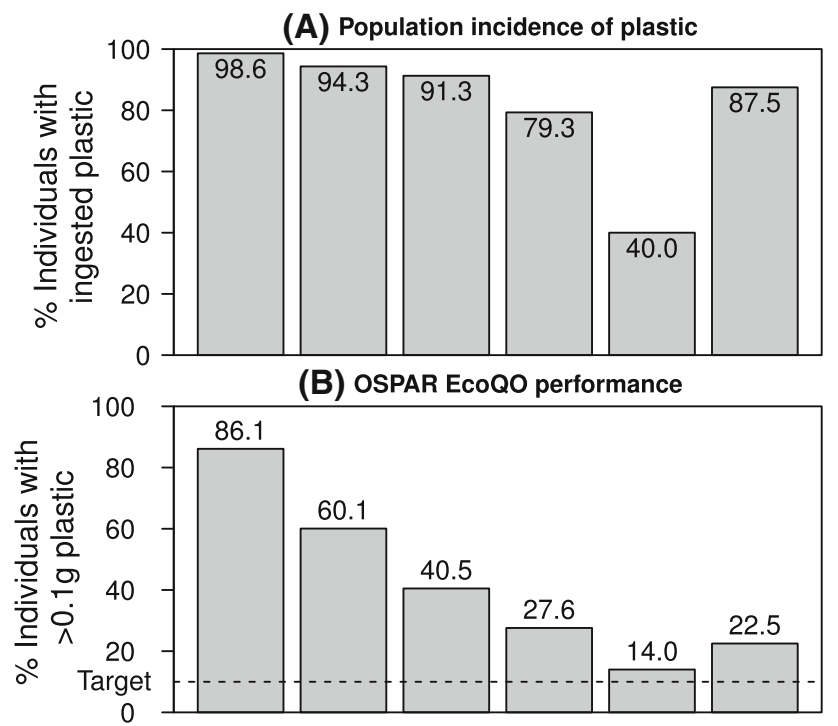

(C) Median and Interquartile Ranges

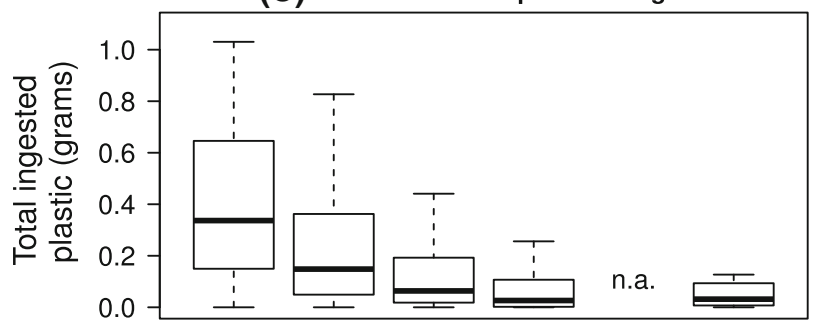

(D) Arithmetic mean

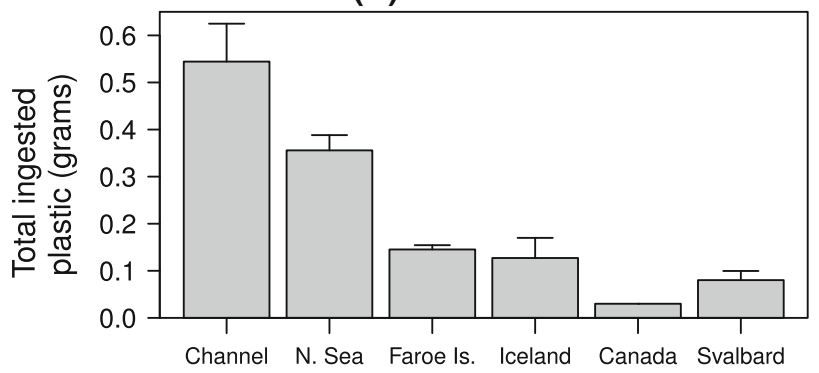

Fig. 3 Regional differences in stomach plastic content of northern fulmars in the North Atlantic, according to a population incidence of stomach plastic, b population incidence of over $0.1 \mathrm{~g}$ of plastic, dashed line shows the Ecological Quality Objective (EcoQO) defined by OSPAR, $\mathbf{c}$ median and interquartile ranges, and $\mathbf{d}$ arithmetic mean mass; error bars show standard error. Data have been collated for the English Channel (Channel, 2007-2011, $n=72$ ), the North Sea (N. Sea, 2007-2011, $n=58$ ), the Faroe Islands (Faroe Is., 2007-2011, $n=699$; Van Franeker and SNS Fulmar Study Group 2013), Iceland (2011, $n=58$; Kühn and Van Franeker 2012), Arctic Canada (Canada, 2002-2009, $n=169$; Mallory et al. 2006; Mallory 2008; Provencher et al. 2009) and Svalbard (2013, $n=40$; this study)

If distance from human impact was the primary driver of plastic ingestion, as previously proposed (Kühn and Van Franeker 2012), levels of plastic ingestion in fulmars from Svalbard would be expected to fall between those in Iceland and Arctic Canada. Indeed, as anticipated, levels on Svalbard are higher than Arctic Canada, where study sites are more remote from population centres. Likewise, compared to the North Sea region (Van Franeker et al. 2011), both lower stomach plastic amounts and higher proportions of user plastics on Svalbard reflect distance from industry and commercial shipping, in accordance with previous theory. However, Svalbard is more remote from human impact than Iceland (Halpern et al. 2008), and yet the amounts of plastic in stomachs of fulmars from the two locations are similar, indicating a need for alternative or additional hypotheses.

The cause of elevated levels of plastic ingestion on Svalbard is uncertain, and therefore, a key knowledge gap for future research has been identified. Transportation of plastic from outside of the Arctic by surface water currents is a likely explanation. Currents along the Norwegian coast may carry floating debris from the polluted North Sea up to the Barents Sea and Svalbard, thus increasing plastic ingestion despite the absence of dense population centres in the region. Van Sebille et al. (2012) hypothesised that converging water currents actually result in an oceanic gyre in the Barents Sea, where plastic litter would accumulate; however, this is yet to be proven. Alternatively, ingested plastic may originate in or around the Barents Sea, either from the Southern Barents Sea fishing fleet (Humphries and Huettmann 2014) or potential release during periods of sea ice melt (Obbard et al. 2014). To confirm or reject these hypotheses would be a useful study for the future and will help to identify how to mitigate plastic in the Arctic.

The high levels of stomach plastic content observed in Svalbard not only highlight the risk to seabirds from plastic pollution, but may also be a considered as a general warning of effects of plastic litter in the Arctic. Floating plastic debris may act as a transport vector to the Arctic for both pollutants (Zarfl and Matthies 2010) and invasive species (Barnes 2002) — both may act as important stressors with threats to biodiversity, particularly under climate warming scenarios (Serreze et al. 2007). Compounds within the plastics may have negative consequences on both wildlife and human health in the region (Oehlmann et al. 2009).

High prevalence of plastic litter in the Arctic, outside of territorial waters, emphasises the need for international mitigation of plastic litter at source, as well as strict enforcement of legislation for commercial activity in the region.

\section{Conclusions}

This study provides a valuable baseline for plastic litter needed to monitor the future impacts of commercial activity in the Arctic. Furthermore, high levels of plastic ingestion in a seabird breeding area at great distance from human impact highlight the need for urgent mitigation of 
Table 1 Stomach plastic content of northern fulmars from Svalbard, according to age

\begin{tabular}{lclcllll}
\hline & $\begin{array}{l}\text { Sample } \\
\text { Size }\end{array}$ & $\begin{array}{l}\text { Incidence of stomach } \\
\text { plastic }(\%)\end{array}$ & $\begin{array}{l}\text { Mean no. of plastic } \\
\text { pieces }(n \pm \mathrm{se})\end{array}$ & $\begin{array}{l}\text { Arithmetic mean } \\
\text { mass }(\mathrm{g} \pm \mathrm{se})\end{array}$ & $\begin{array}{l}\text { Max stomach } \\
\text { plastic }(\mathrm{g})\end{array}$ & $\begin{array}{l}\text { Geometric } \\
\text { mean mass }\end{array}$ & $\begin{array}{l}\text { EcoQO } \\
\text { performance } \\
(\%)\end{array}$ \\
\hline All & 40 & 87.5 & $15.32 \pm 5.51$ & $0.08 \pm 0.02$ & 0.50 & 0.023 & 22.5 \\
Adults & 5 & 80 & $4.20 \pm 2.52$ & $0.04 \pm 0.02$ & 0.12 & 0.013 & 20 \\
Non-adults & 35 & 89 & $16.91 \pm 6.25$ & $0.09 \pm 0.02$ & 0.50 & 0.025 & 22.9 \\
\hline
\end{tabular}

Averages are given in number $(n)$ or grams $(\mathrm{g})$ of plastic per individual \pm standard error. Maximum stomach plastic content is by a single individual in the age class. EcoQO performance gives the percentage of the population with more than $0.1 \mathrm{~g}$ of ingested plastic

Table 2 Stomach plastic content of northern fulmars from Svalbard $(n=40)$, according to type of plastic

\begin{tabular}{llllll}
\hline & $\begin{array}{l}\text { Incidence } \\
(\%)\end{array}$ & $\begin{array}{l}\text { Mean number of } \\
\text { plastic pieces }(n \pm \mathrm{se})\end{array}$ & $\begin{array}{l}\text { Arithmetic mean } \\
\text { mass }(\mathrm{g} \pm \mathrm{se})\end{array}$ & $\begin{array}{l}\text { Max stomach } \\
\text { plastic }(\mathrm{g})\end{array}$ & $\begin{array}{l}\text { Geometric mean } \\
\text { mass }\end{array}$ \\
\hline All plastics & 87.5 & $15.32 \pm 5.51$ & $0.080 \pm 0.02$ & 0.499 & 0.023 \\
$\quad$ Industrial plastic & 23 & $0.45 \pm 0.17$ & $0.006 \pm 0.00$ & 0.051 & 0.001 \\
User plastic & 83 & $14.88 \pm 5.41$ & $0.074 \pm 0.02$ & 0.490 & 0.018 \\
$\quad$ Sheet like & 35 & $1.53 \pm 0.53$ & $0.004 \pm 0.00$ & 0.071 & 0.001 \\
Thread like & 45 & $1.90 \pm 0.61$ & $0.018 \pm 0.01$ & 0.318 & 0.002 \\
Foamed & 10 & $0.68 \pm 0.45$ & $0.000 \pm 0.00$ & 0.008 & 0.000 \\
Fragments & 80 & $10.72 \pm 4.60$ & $0.049 \pm 0.02$ & 0.480 & 0.013 \\
Other & 5 & $0.05 \pm 0.03$ & $0.003 \pm 0.00$ & 0.082 & 0.000 \\
\hline
\end{tabular}

Averages are given in number $(\mathrm{n})$ or grams $(\mathrm{g})$ of plastic per individual \pm standard error. Maximum stomach plastic content is by a single individual

plastic pollution in the Arctic as well as implementation of strict regulation for future commercial activity.

Acknowledgments This work was funded in full by Svalbard Miljøvernfond and the Nordic Council. Thanks to participants in the Save the North Sea monitoring projects for providing data shown in Fig. 3. Many thanks also to anonymous reviewers for improvements to the manuscript.

Open Access This article is distributed under the terms of the Creative Commons Attribution License which permits any use, distribution, and reproduction in any medium, provided the original author(s) and the source are credited.

\section{References}

Avery-Gomm S, O'Hara PD, Kleine L et al (2012) Northern fulmars as biological monitors of trends of plastic pollution in the eastern North Pacific. Mar Pollut Bull 64:1776-1781. doi:10.1016/j. marpolbul.2012.04.017

Barnes DKA (2002) Biodiversity: invasions by marine life on plastic debris. Nature 416:808-809. doi:10.1038/416808a

Barnes DKA (2005) Remote islands reveal rapid rise of southern hemisphere, sea debris. Sci World J 5:915-921. doi:10.1100/tsw. 2005.120

Bergmann M, Klages M (2012) Increase of litter at the Arctic deepsea observatory HAUSGARTEN. Mar Pollut Bull 64:27342741. doi:10.1016/j.marpolbul.2012.09.018

Brigham L (2011) Marine protection in the Arctic cannot wait. Nature 478:157. doi:10.1038/478157a
Donnelly-Greenan EL, Harvey JT, Nevins HM et al (2014) Prey and plastic ingestion of Pacific Northern Fulmars (Fulmarus glacialis rogersii) from Monterey Bay, California. Mar Pollut Bull 85:214-224. doi:10.1016/j.marpolbul.2014.05.046

Edwards EWJ, Quinn LR, Wakefield ED et al (2013) Tracking a northern fulmar from a Scottish nesting site to the Charlie-Gibbs Fracture Zone: evidence of linkage between coastal breeding seabirds and Mid-Atlantic Ridge feeding sites. Deep Sea Res Part 2 Top Stud Oceanogr 98:438-444. doi:10.1016/j.dsr2.2013. 04.011

Eriksen M, Lebreton LCM, Carson HS et al (2014) Plastic pollution in the world's oceans: more than 5 trillion plastic pieces weighing over 250,000 tons afloat at Sea. PLoS One 9:e111913. doi:10.1371/journal.pone.0111913

France R (1992) Garbage in paradise. Nature 355:504

Garthe S, Montevecchi WA, Ojowski U, Stenhouse IJ (2004) Diets of northern fulmar (Fulmarus glacialis) chicks in the northwest Atlantic Ocean. Polar Biol 27:277-280

Gjertz I, Mehlum F, Gabrielsen GW (1985) Food sample analysis of seabirds collected during the "Lance"-cruise in ice-filledwaters in Eastern Svalbard 1984. 21

Halpern BS, Walbridge S, Selkoe KA et al (2008) A global map of human impact on marine ecosystems. Science 319:948-952. doi:10.1126/science. 1149345

Hamer KC, Thompson DR, Gray CM (1997) Spatial variation in the feeding ecology, foraging ranges, and breeding energetics of northern fulmars in the north-east Atlantic Ocean. ICES J Mar Sci 54:645-653. doi:10.1006/jmsc.1997.0242

Humphries GRW, Huettmann F (2014) Putting models to a good use: a rapid assessment of Arctic seabird biodiversity indicates potential conflicts with shipping lanes and human activity. Divers Distrib 20:478-490. doi:10.1111/ddi.12177 
Kerr RA (2012) Climate change. Ice-free Arctic sea may be years, not decades, away. Science 337:1591. doi:10.1126/science.337. 6102.1591

Kühn S, Van Franeker JA (2012) Plastic ingestion by the northern fulmar (Fulmarus glacialis) in Iceland. Mar Pollut Bull 64:1252-1254

Laist DW (1997) Impacts of marine debris: entanglement of marine life in marine debris including a comprehensive list of species with entanglement and ingestion records. In: Coe JM, Rogers DB (eds) Marine debris. Springer New, York, pp 99-139

Law KL, Thompson RC (2014) Microplastics in the seas. Science 80(345):144-145. doi:10.1126/science.1254065

Leggett C, Scherer N, Curry M, Bailey R (2014) Assessing the economic benefits of reductions in marine debris: a pilot study of beach recreation in Orange County, California. NOAA Mar Debris Progr Ind Econ Inc 45

Lydersen C, Gjertz I (1989) Stomach contents of autumn-feeding marine vertebrates from Hornsund, Svalbard. Polar Rec (Gr Brit) 25:107-114

Lydersen C, Gjertz I, Weslawski JM (1985) Aspects of vertebrate feeding in the marine ecosystem in Hornsund, Svalbard. 57

Mallory ML (2008) Marine plastic debris in northern fulmars from the Canadian high Arctic. Mar Pollut Bull 56:1501-1504. doi:10. 1016/j.marpolbul.2008.04.017

Mallory ML, Roberston GJ, Moenting A (2006) Marine plastic debris in northern fulmars from Davis Strait, Nunavut, Canada. Mar Pollut Bull 52:813-815

Mouat J, Lozano RL, Bateson H (2010) Economic impacts of marine litter. 105

Obbard RW, Sadri S, Wong YQ et al (2014) Global warming releases microplastic legacy frozen in Arctic Sea ice. Earth's Future 2:315-320. doi:10.1002/2014EF000240

Oehlmann J, Schulte-Oehlmann U, Kloas W et al (2009) A critical analysis of the biological impacts of plasticizers on wildlife. Philos Trans R Soc Lond B Biol Sci 364:2047-2062. doi:10. 1098/rstb.2008.0242

OSPAR (2008) Background document for the EcoQO on plastic particles in stomachs of seabirds. OSPAR Commission, Biodiversity Series

Plastics Europe (2013) Plastics-the Facts 2013. An analysis of European latest plastics production, demand and waste data. 40. http://www.plasticseurope.org/Document/plastics-the-facts-2013. aspx?FolID=2. Accessed 1 Feb 2015
Provencher JF, Gaston AJ, Mallory ML (2009) Evidence for increased ingestion of plastics by northern fulmars (Fulmarus glacialis) in the Canadian Arctic. Mar Pollut Bull 58:1092-1095

Riotte-Lambert L, Weimerskirch H (2013) Do naive juvenile seabirds forage differently from adults? Proc Biol Sci 280:20131434. doi:10.1098/rspb.2013.1434

Serreze MC, Holland MM, Stroeve J (2007) Perspectives on the Arctic's shrinking sea-ice cover. Science 315:1533-1536. doi:10.1126/science.1139426

Smith LC, Stephenson SR (2013) New trans-Arctic shipping routes navigable by midcentury. Proc Natl Acad Sci USA 110:E1191E1195. doi:10.1073/pnas.1214212110

Van Franeker JA (1985) Plastic ingestion in the North Atlantic fulmar. Mar Pollut Bull 16:367-369

Van Franeker JA (2004) Save the North Sea fulmar-litter-EcoQO manual part 1: collection and dissection procedures. 38. http:// edepot.wur.nl/40451. Accessed 1 Feb 2015

Van Franeker JA, SNS Fulmar Study Group (2013) Fulmar Litter EcoQO monitoring along Dutch and North Sea coasts-update 2010 and 2011. 61

Van Franeker JA, Meijboom A (2002) Marine litter monitoring by Northern fulmars: a pilot study. 72

Van Franeker JA, Blaize C, Danielsen J et al (2011) Monitoring plastic ingestion by the northern fulmar Fulmarus glacialis in the North Sea. Environ Pollut 159:2609-2615

Van Sebille E, England MH, Froyland G (2012) Origin, dynamics and evolution of ocean garbage patches from observed surface drifters. Environ Res Lett. doi:10.1088/1748-9326/7/4/044040

Votier SC, Grecian WJ, Patrick S, Newton J (2010) Inter-colony movements, at-sea behaviour and foraging in an immature seabird: results from GPS-PPT tracking, radio-tracking and stable isotope analysis. Mar Biol 158:355-362. doi:10.1007/ s00227-010-1563-9

Weimerskirch H, Chastel O, Cherel Y et al (2001) Nest attendance and foraging movements of northern fulmars rearing chicks at Bjørnøya Barents Sea. Polar Biol 24:83-88

WRAP (2014) UK voluntary carrier bag monitoring —2013 data. 26. http://www.wrap.org.uk/sites/files/wrap/Carrier\%20Bag\%20results \%202013.pdf . Accessed 1 Feb 2015

Zarfl C, Matthies M (2010) Are marine plastic particles transport vectors for organic pollutants to the Arctic? Mar Pollut Bull 60:1810-1814. doi:10.1016/j.marpolbul.2010.05.026 